\title{
The Release Behavior, Biocompatibility and Physical Properties of Ald-loaded Strontium Doped Calcium Phosphate Cement
}

\author{
Maryam Mohammadi $^{1}$, Sayed Mahmood Rabiee ${ }^{1^{*}}$, Saeed Hesaraki ${ }^{2}$ \\ 1. Department of Materials Engineering, Babol Noshirvani University of Technology, Babol 71167-47148, Iran \\ 2. Nanotechnology and Advanced Materials, Materials and Energy Research Center, Karaj 3177983634, Alborz, Iran
}

\begin{abstract}
The effect of concurrent attendance of two inhibitors of bone degradation, namely Alendronate (Ald) sodium trihydrate and Strontium (Sr), on Calcium Phosphate Cement (CPC) characteristics was explored. To this aim, $5 \mathrm{wt} \%$ Strontium and $21 \mathrm{mM}$ Alendronate sodium trihydrate were used in calcium phosphate cement and setting time, ion and drug release were analyzed. RAW264.7 and G cell were cultured on cement samples and Tartrate-Resistant Acid Phosphatase (TRAP), Alkaline phosphatase (ALP) activity and MTT assay were studied. The results of structural analysis indicated that $21 \mathrm{mM}$ Ald did not let the cement set. Therefore, colloidal silica was added to the cement formula and successfully decreased the setting time. In vitro tests showed Sr-loaded sample had a greater inhibitory effect on biocompatibility of G cells than Ald-loaded and Sr-Ald-loaded samples. In addition, the findings about osteoblast MTT and ALP activity indicated that Sr was more effective in osteogenic activity of G cells. The simultaneous presence of Ald and Sr in Calcium Phosphate Cement (CPC) was not as effective in its biocompatibility as the presence of $\mathrm{Sr}$ alone.
\end{abstract}

Keywords: calcium phosphate cements, drug release, alendronate sodium trihydrate, strontium, RAW264.7 cell, G cell

Copyright $($ The author(s) 2020.

\section{Introduction}

Osteoporosis is well known for deteriorating bone structure and causing low bone mass. This disease is expected to be a gradually growing universal medical issue with population ageing. Osteoporosis exerts a great influence on life quality by significantly increasing the probability of hip bone fracture, distal forearm, and vertebra $^{[1-3]}$. Using injectable bone cement in minimally invasive surgery for treating bone defect or stabilizing osteoporosis has significant clinical prospects ${ }^{[3-5]}$. Calcium Phosphate Cement (CPC) is a new generation of injectable bone cements regarded as a material with capabilities for bone defect treatment with excellent bioactivity, osteotransductivity, and biocompatibility. CPC can be the best substitute for hard tissues since, after implantation, it rapidly integrates into the bone structure and becomes a new bone ${ }^{[5-8]}$.

Using CPCs as a local carrier for drugs like antibiotics, antitumors, osteoporosis, and growth factors can also be an option in extended treatments to accelerate bone healing ${ }^{[9-11]}$. Adding drugs to CPCs probably im- pacts the general physicochemical characteristics of cement, e.g., setting time, mechanical strength, rheological properties, and the microstructure. As an instance, drugs of tetracycline type in the CPCs may chelate with $\mathrm{Ca}^{2+}$ ions, causing mineral precipitation and nucleation and therefore, prolonging the setting reaction ${ }^{[11,12]}$. Bisphosphonates (BPs) are highly active inhibitor agents of bone degradation. It is reported that BPs can inhibit osteoclast activities and lead to apoptosis of the cells ${ }^{[13-15]}$. Alendronate as a BP encourages bone formation and impedes bone resorption. In comparison with other BPs, Alendronate (Ald) is firmly adsorbed by the bone and barely detached. Even in case of desorption, its reattachment is definite. Systemic administration of BPs is subject to many reactions and aftereffects such as jaw osteonecrosis, specifically occurring with intravenous formulations more prevalently in oncologic patients receiving drugs at high doses. CPCs have been proposed to reduce side effects of systemic administration of $\mathrm{BPs}^{[14-16]}$.

Ionic doping, e.g., $\mathrm{Ag}^{+}, \mathrm{Zn}^{2+}, \mathrm{Mg}^{2+}, \mathrm{Sr}^{2+}$, etc., affects bioactive ceramics properties such as drug loading

\footnotetext{
*Corresponding author: Sayed Mahmood Rabiee

E-mail: rabiee@nit.ac.ir
} 
and release efficiency, crystal structure, phase composition, structural properties, solubility of calcium phosphate, host tissue response, and antimicrobial activity ${ }^{[17-19]}$. A necessary trace element in body is strontium ( $\mathrm{Sr}$ ). It is proved that $\mathrm{Sr}$ improves bone formation, on the one hand, and diminishes resorption of bone via increased osteoclast apoptosis, enhanced collagen synthesis, and osteoblastic cell proliferation, on the other hand ${ }^{[19,20]}$.

The development of Sr-loaded CPCs has been with the aims of enhancing chemical and biological responses to repair bones and achieving better bioactivity. Introduction of even a small amount of $\mathrm{Sr}^{2+}$ into CPCs has been reported to promote differentiation and proliferation of osteoblasts and impede forming and functioning of osteoclasts. In addition, considerable evidence exists for the positive impacts of $\mathrm{Sr}$ on regeneration of bones, which has encouraged scientists to add $\mathrm{Sr}$ into CPCs formula ${ }^{[21,22]}$. To this aim, we synthesized $\mathrm{Sr}-\beta-\mathrm{TCP}$ as a main component of cement powder in the cement powder phase. $\beta$-Tri-Calcium Phosphate ( $\beta$-TCP) is an enviable mineral for bone treatment programs due to its better resorbable characteristics than hydroxyapatite $(\mathrm{HA})^{[23]}$. $\beta$-TCP in biological systems disintegrates in two ways, namely chemical dissolution and osteoclastic resorption process, and provides the surface for employment of osteoblast cells. New bone is created on the prepared surfaces by osteoblast cells and then, the process of bone remodeling begins. Considering the fact that the preliminary constituents of biological tissues like bone and teeth are made of calcium phosphate mineral phases with various elements, $\beta$-TCP chemical modification via ionic substitutions attracted scientists' attention $^{[18,23]}$.

The presence of $\mathrm{Sr}$ and Ald simultaneously in CPC may enhance their inhibitory effect on bone cells. Hence, we investigated their effects on cement properties as well as the in vitro $\mathrm{G}$ and raw 264 cells responses.

\section{Materials and methods}

\subsection{Cement preparation}

Beta tricalcium Phosphate [ $\beta$-TCP: $\left.\beta-\mathrm{Ca}_{3}\left(\mathrm{PO}_{4}\right)_{2}\right]$ was obtained through heating a blend of calcium carbonate $\left[\mathrm{CC}: \mathrm{CaCO}_{3}\right]$ and dicalcium phosphate anhydrous [DCPA: $\mathrm{CaHPO}_{4}$ ] at a molar ratio of $1: 2$ for $6 \mathrm{~h}$ at a temperature of $1200{ }^{\circ} \mathrm{C}$ and then cooling in the furnace. To synthesize $5 \mathrm{wt} \% \mathrm{Sr}-\beta \mathrm{TCP}$, to the mixture, Sr carbonate $\mathrm{SrCO}_{3}$ (Merck, India) was added, replacing $\mathrm{CaCO}_{3}$ at 17.70 weight percentage. The sintered cakes were crushed and sieved to prepare two different groups of cement powders. The first group of samples was prepared by mixing $70 \mathrm{wt} \% \beta$-TCP powder with $25 \mathrm{wt} \%$ DCPA and $5 \mathrm{wt} \% \mathrm{CC}$ and the second group by $5 \mathrm{wt} \%$ Sr- $\beta$ TCP instead of $\beta$-TCP. Size distribution of the powder particles was analyzed by Fritsch Analaysate laser particle size analyzer. The base of liquid phase for all samples was $3 \mathrm{wt} \% \mathrm{Na}_{2} \mathrm{HPO}_{4}$ in deionized water. In colloidal silica (30 $\mathrm{wt} \%$ suspension in $\mathrm{H}_{2} \mathrm{O}$, Sigma-Aldrich) loaded samples, $40 \mathrm{v} \%$ liquid phase was colloidal silica and in drug-loaded samples, liquid phase was $21 \mathrm{mM}$ Ald sodium trihydrate (Arasto Iran) in $3 \mathrm{wt} \% \mathrm{Na}_{2} \mathrm{HPO}_{4}$. The liquid/powder $(\mathrm{L} / \mathrm{P})$ ratio of the cement was $0.035 \mathrm{~mL} \cdot \mathrm{g}^{-1}$. Powders and liquids were mixed for about $1 \mathrm{~min}$ to prepare the cement samples.

The method of drug loading in CPC has a significant effect on different parameters such as drug distribution in the cement matrix, mechanical strength, and setting time. Studies have shown that when drug is incorporated in the cement liquid phase, high homogeneity is achieved in comparison with mixing drug with powder phase. For drug-loaded samples, the liquid phase of cement is a mixture of colloidal silica and $3 \mathrm{wt} \%$ $\mathrm{Na}_{2} \mathrm{HPO}_{4}$ in deionized water at a volume ratio of 40: 60 . Accordingly, $60 \mathrm{v} \%$ liquid phase contained $35 \mathrm{mM}$ Ald in $3 \mathrm{wt} \% \mathrm{Na}_{2} \mathrm{HPO}_{4}$ solution as a result each drug loaded sample contained $21 \mathrm{mM}$ Ald (Table 1).

\subsection{Cement characterization}

\subsection{1 $X$-ray diffraction}

Cement samples phase analysis was performed

Table 1 Samples formulation

\begin{tabular}{cccc}
\hline Sample & $\begin{array}{c}\text { Colloidal silica } \\
(\mathrm{v} \%)\end{array}$ & $\begin{array}{c}\text { Alendronate sodium } \\
\text { trihydrate (Ald) }\end{array}$ & $\begin{array}{c}\text { Strontium } \\
\text { (Sr) wt\% }\end{array}$ \\
\hline 0Sr-0Ald-0CS & 0 & 0 & 0 \\
5Sr-0Ald-0CS & 0 & 0 & 5 \\
0Sr-21Ald-0CS & 0 & 21 & 0 \\
5Sr-21Ald-0CS & 0 & 21 & 5 \\
0Sr-0Ald-40CS & 40 & 0 & 0 \\
5Sr-0Ald-40CS & 40 & 0 & 5 \\
0Sr-21Ald-40CS & 40 & 21 & 0 \\
5Sr-21Ald-40CS & 40 & 21 & 5 \\
\hline
\end{tabular}


using $X$-ray diffractometer (Phillips PW3710) by Co-K $\alpha$ radiation at $20 \mathrm{KV}$ operating voltage. Cement $X$-ray patterns were controlled and checked following the standards of the International Center for Diffraction Data (ICDD). The collected data comprised $10^{\circ}$ to $70^{\circ}$ for $2 \theta$ with the step size of $0.01^{\circ}$. $X$-ray diffraction patterns of Sr- $\beta$ TCP powders were captured from $2 \theta=28^{\circ}-$ $44^{\circ}$ with a step size of 0.005 and a normalized count time of 0.8 second per step. Refinement analysis of Rietveld was employed to determine lattice parameter changes of Sr-substituted $\beta$-TCP.

\subsubsection{Morphological analysis}

Morphology of the cement surfaces was analyzed before and after their immersion in Ringer's solution through Scanning Electron Microscopy (SEM). Gold coating was used to cover the sample surfaces prior to the examination.

\subsubsection{Setting times}

Gillmore needle was employed to assess the initial and final setting times of cement based on the ASTM: C 266-89 standard. A narrow needle with the diameter of $1.063 \mathrm{~mm}$ and the weight of $113.4 \mathrm{~g}$ was utilized to measure the initial setting time and a thick, heavy needle characterized by a diameter of $1.06 \mathrm{~mm}$ and a weight of $453.6 \mathrm{~g}$ for measuring the final setting time ${ }^{[19]}$. To this aim, a needle was placed out on a cement sample surface and the cement was considered to be set once the needle made no visual mark on the surface. For each reported data, at least five specimens were tested.

\subsubsection{Ion release}

Cement pills were immersed in $10 \mathrm{~mL}$ PBS solution and incubated in an incubator at a temperature of $37^{\circ} \mathrm{C}$ with $99 \%$ humidity. Concentrations of the $\mathrm{Sr}^{2+}$ and $\mathrm{Ca}^{2+}$ ions $(n=3)$ were measured at different intervals and the immersion liquid was substituted after every measurement in a dynamic mode. Inductively coupled plasma mass spectroscopy was carried out to calculate the concentrations of ions.

\subsubsection{Ald sodium trihydrate release}

Two hours after liquid and powder phase mixing, cement samples were introduced into $5 \mathrm{~mL}$ PBS and incubated at $37^{\circ} \mathrm{C}$. By collecting the PBS after $0.5 \mathrm{~h}, 1 \mathrm{~h}$, $2 \mathrm{~h}, 3 \mathrm{~h}, 8 \mathrm{~h}, 24 \mathrm{~h}$, and once every day for $7 \mathrm{~d}$, the released quantity of Ald from the cements was investigated in triplicates. The whole medium of dissolution was substituted with fresh buffer during the test of release. The withdrawn buffer solution was first filtered and then, rinsed in a perchloric acid/iron (III) chloride solution. The released Ald concentration was specified by a chromophoric complex of iron (III) ions with Ald by using ultraviolet (UV) spectrophotometry.

To clearly perceive the underlying mechanisms involved in drug release, its patterns were assessed by a number of mathematical models, namely, zero-order, first-order, Weibull, Higuchi, Hixson-Crowell, Peppas, Hopfenberg, and Baker-Lonsdale. Peppas (Eq. (1)) and Weibull (Eq. (2)) equations were used as pharmaceutical release models for the release profiles. To identify the kinetics of release, the semi-empirical power law (Peppas) model was employed ${ }^{[24]}$ :

$$
\begin{aligned}
& M_{t} / M_{0}=k t^{n}, \\
& M_{t} / M_{0}=1-\exp \left(-(t / \tau)^{d}\right),
\end{aligned}
$$

where $M_{t}$ is the drug mass released at time $t, M_{0}$ the drug mass released with time approaching infinity, $n$ the diffusional coefficient indicating the transport mechanism, and $\mathrm{k}$ a constant representing the properties of the macromolecular network system and the drug ${ }^{[25]}$. The diffusional exponent was a function of sample geometry. Diffusion-controlled release (Fickian diffusion) was $n=0.50, n=0.45$, and $n=0.43$ in thin film, cylindrical, and spherical samples, respectively.

\subsection{In vitro study}

\subsubsection{RAW264.7 cell culture and seeding}

RAW264 murine macrophage cell line was cultured in Dulbecco's Modified Eagle's Medium (DMEM) containing $10 \%$ FBS. After directly seeding them on the sample surfaces $(\Phi 6 \mathrm{~mm} \times 2 \mathrm{~mm})$ in a 24-well plate, the cells were incubated in an incubator with $5 \%$ $\mathrm{CO}_{2}$ at a temperature of $37{ }^{\circ} \mathrm{C}$. The culture medium received $50 \mathrm{ng} \cdot \mathrm{mL}^{-1}$ RANKL (Biolegend, CA, USA) in the first day. In the following stages of the experiment, the cell medium was substituted every $24 \mathrm{~h}$. The disks of 0Sr-0Ald-0CS, 5Sr-0Ald-0CS, 0Sr-0Ald-40CS, 
5Sr-0Ald-40CS, 0Sr-21Ald-40CS, and 5Sr-21Ald40CS underwent incubation with RAW264.7 cells in an atmosphere of $5 \% \mathrm{CO}_{2}$ at a temperature of $37{ }^{\circ} \mathrm{C}$ for three days, but the medium did not receive RANKL.

\subsubsection{Osteoclast cell morphology}

Morphology of the cells was closely analyzed through Field Emission Scanning Electron Microscopy (FESEM). Undergoing incubation for three days, the samples were taken out from the culture medium after three days of incubation and rinsed with $0.1 \mathrm{M}$ PBS. Then, they were fixed in $2.5 \%$ glutaraldehyde with phosphate buffer $0.01 \mathrm{M}$ at $\mathrm{pH} 7.4$ and dehydrated in an ethanol series $(30 \%, 50 \%, 60 \%, 70 \%, 80 \%, 90 \%$, and $100 \%$ ), followed by hexamethyl-disililane drying. The dried samples were gold coated and cell morphology was perused through FESEM.

\subsubsection{TRAP activity}

Following the protocols, the activity of Tartrate-Resistant Acid Phosphatase (TRAP) was calculated as a specific feature of osteoclasts ${ }^{[26]}$. After culturing for $3 \mathrm{~d}$, adherent RAW264 cells lysed in $1 \mathrm{M} \mathrm{NaCl}$ with $0.2 \%$ Triton $\mathrm{x}-100$. The lysate underwent incubation with $60 \mathrm{~mL}$ of $5 \mathrm{mM}$ p-nitrophenyl phosphate (Sigma, USA) in $25 \mathrm{mM}$ Na-acetate $/ 20 \mathrm{mM}$ Natartrate, $\mathrm{pH} 4.9$, for $35 \mathrm{~min}$. Adding $0.5 \mathrm{M} \mathrm{NaOH}$ impeded the reaction. $100 \mu \mathrm{L}$ of the obtained supernatant was displaced into a plate and read at $405 \mathrm{~nm}$.

\subsubsection{Osteoblast culture}

To the cultured $\mathrm{G}$ human osteoblast-like cells in DMEM medium (Sigma, UK), 10\% FCS and antibiotics (80 $\mathrm{mg} \cdot \mathrm{mL}^{-1}$ streptomycin, $80 \mathrm{U} \cdot \mathrm{mL}^{-1}$ penicillin) were added. Being taken out from the culture flasks, the cells at an appropriate density $\left(3 \times 10^{4}\right.$ cells $\left.\cdot \mathrm{mL}^{-1}\right)$ were put in 96-well plates with four sterile samples for each group. Then, they were seeded in empty wells in order to manage the experiment at the same concentration. To activate osteoblasts, DMEM was substituted for the medium and $\beta$-Glycerophosphate $(10 \mathrm{M})$ and ascorbic acid $\left(55 \mu \mathrm{g} \cdot \mathrm{mL}^{-1}\right)$ were added. The culture of the cells was performed in standard conditions at $37{ }^{\circ} \mathrm{C} \pm 0.4{ }^{\circ} \mathrm{C}$ with $95 \%$ humidity and $5 \% \mathrm{CO}_{2}$.

\subsubsection{Osteoblast morphology}

Samples were processed for FESEM at the final stage of the experiment. G cells were stabilized on the materials in 3\% glutaraldehyde with PBS at $\mathrm{pH} 7.4$ for $1 \mathrm{~h}$ and dehydrated in a graded ethanol series. The samples were coated by sputter deposition with Au before examination with a TE SCAN MIRA3 SEM.

\subsubsection{Alkaline phosphatase (ALP) activity}

G cells underwent lysis by a commercial buffer following the instructions of the manufacturer (CelLytic M, Sigma Aldrich). 1 g L-1 p-nitrophenyl phosphate (pNPP) with the volume of $170 \mu \mathrm{L}$ was dissolved in $0.2 \mathrm{M}$ tris buffer (Sigma-Aldrich) and the obtained solution was added to $30 \mu \mathrm{L}$ cell lysate. After incubation of the samples at $37^{\circ} \mathrm{C}$ for an hour, adding $20 \mu \mathrm{L}$ of $0.3 \mathrm{M}$ $\mathrm{NaOH}$ ended the reaction. Then, p-nitrophenyl concentration in the solution after incubating for an hour was specified by reading the absorbance at $405 \mathrm{~nm}$.

\subsubsection{MTT assay}

To evaluate the cell functionality of the samples, MTT assay (3-(4,5-Dimethylthiazol-2-yl)-2,5- Diphenyltetrazolium Bromide) was used. An attempt was made to seed G cells into a 96-well plate in standard culturing conditions at the appropriate density $\left(2 \times 10^{4}\right.$ cells per well). Then, they were incubated on the samples for three and $7 \mathrm{~d}$. Following the incubation, the medium was taken away and another medium that contains $10 \%$ MTT solution was included. Next, the plates were incubated for $4 \mathrm{~h}$ at a temperature of $37{ }^{\circ} \mathrm{C}$. The medium was then taken away and $100 \mu \mathrm{L}$ solubilization buffer $(0.1 \mathrm{~N} \mathrm{HCl}$, Triton-X 100, and isopropanol) was injected to each well to dissolve the produced formazan crystals by living cell activities in MTT solution. The lysate absorbance was determined at $570 \mathrm{~nm}$.

\subsection{Statistical analysis}

This study carried out each of the intended experiments five times and reported the results of the means \pm standard deviations. Tukey's multiple comparison tests and ANOVA were employed to study the possible differences of experimental classes. When $p$ was lower than 0.05 , differences were significant, statistically. 


\section{Results}

\subsection{Cement characterization}

\subsubsection{Setting times}

The influence of incorporating Ald, Sr, and colloidal silica on CPCs setting times is shown in Fig. 1. In general, adding drug caused longer setting time. After adding $21 \mathrm{mM}$ Ald to 0 Sr-0Ald-0CS and 5Sr-0Ald-0CS, initial setting time increased $(p<0.05)$ from $31 \mathrm{~min}$ and $38 \mathrm{~min}$ to $56 \mathrm{~min}$ and $55 \mathrm{~min}$, respectively. The presence of $\mathrm{Sr}$ in the composition of cements did not have anysignificant effect on setting times, but adding colloidal silica and drug simultaneously decreased $(p<0.05)$ the setting time of drug-loaded samples.

\subsubsection{Phase composition and microstructural analysis}

Figs. $2 \mathrm{a}$ and $2 \mathrm{~b}$ depict the $X$-ray diffraction patterns of the as-set CPCs and the samples following their immersion in Ringer's solution for $7 \mathrm{~d}$. In the as-set cement group, the starting materials containing monetite (ICDD 01-70-360), Calcite (ICDD 01-072-1937), and synthesized $\beta$-TCP (ICDD 01-070-2065) were present (Fig. 2a). Moreover, after immersing in Ringer's solution, no specific evolution was seen and $\beta$-TCP was the predominant phase after $7 \mathrm{~d}$ (Fig. 2b). The same results were observed for Sr doped, Ald and colloidal silica-loaded samples, as given in Fig. 2. $X$-ray peaks of 5Sr composition slightly shifted to lower $2 \theta$ angles than those of the 0Sr samples. On the other hand, peak broadening was observed with Sr-doped and Ald-loaded samples. Obviously, no diffraction data were observed with $\mathrm{n}-\mathrm{SiO}_{2}$ because of its amorphous nature.

Fig. 3 shows SEM images for various cements before (as-set) and following their soaking in Ringer's solution for $7 \mathrm{~d}$. Following $7 \mathrm{~d}$, apatite crystals were observed in control cement (0Sr-0Ald-0CS), which were not detectable by $X$-ray diffraction. They were not seen in the (5Sr-0Ald-0CS) sample and $\mathrm{Sr}$ doping apparently inhibited apatite formation. Adding colloidal silica to the CPC formula had positive effect on cement hydration and apatite formation (0Sr-0Ald-40CS and 5Sr-0Ald $-40 \mathrm{CS}$ ) and newly formed apatite crystals were observed in both samples. In drug-loaded samples, no phase transition occurred (0Sr-21Ald-40CS and 5Sr-21Ald-40CS) $7 \mathrm{~d}$ after soaking in Ringer's solution. In general, ac- cording to the SEM micrograph, adding colloidal silica encompassed the microstructure and gave a more compact structure.

\subsubsection{Ions release}

To calculate $\mathrm{Ca}^{2+}$ and $\mathrm{Sr}^{2+}$ release, sample ageing in

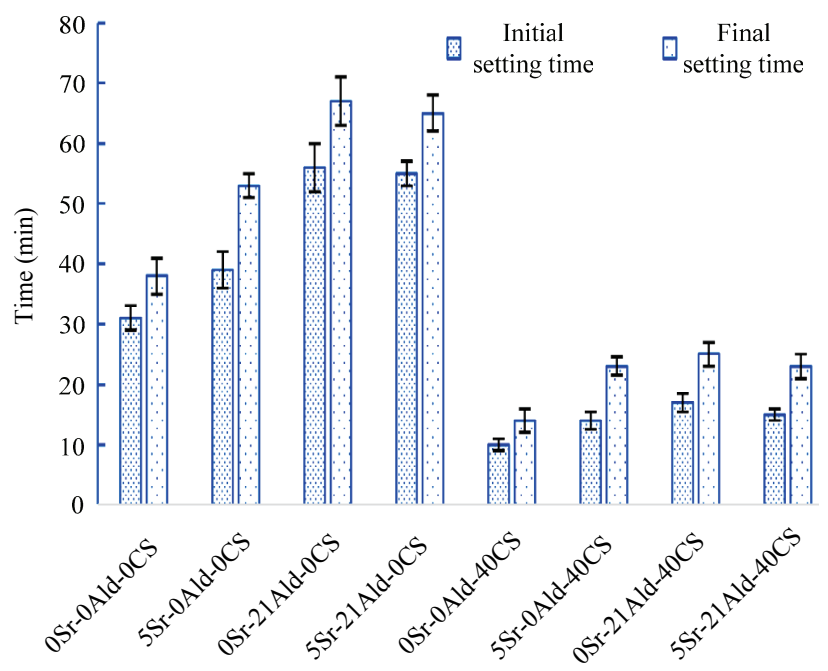

Fig. 1 Setting times of cement samples.

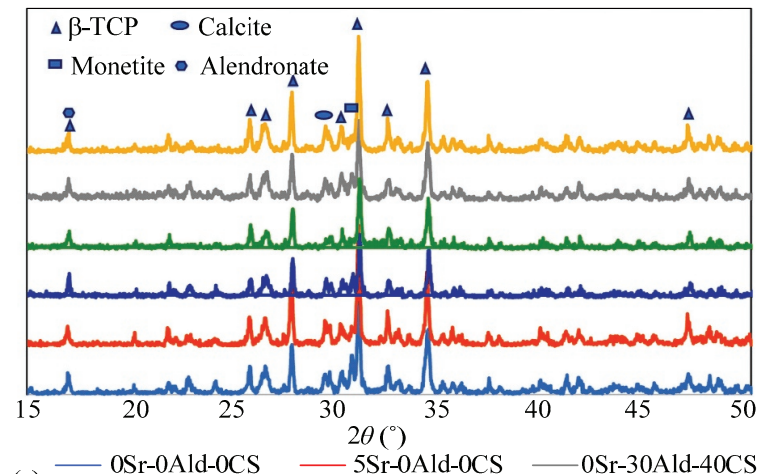

(a) $\begin{gathered}\text { OSr-0Ald-0CS } \\ \text { 5Sr-30Ald-40CS } 5 \mathrm{Sr}-0 \mathrm{Ald}-0 \mathrm{CS}\end{gathered}$

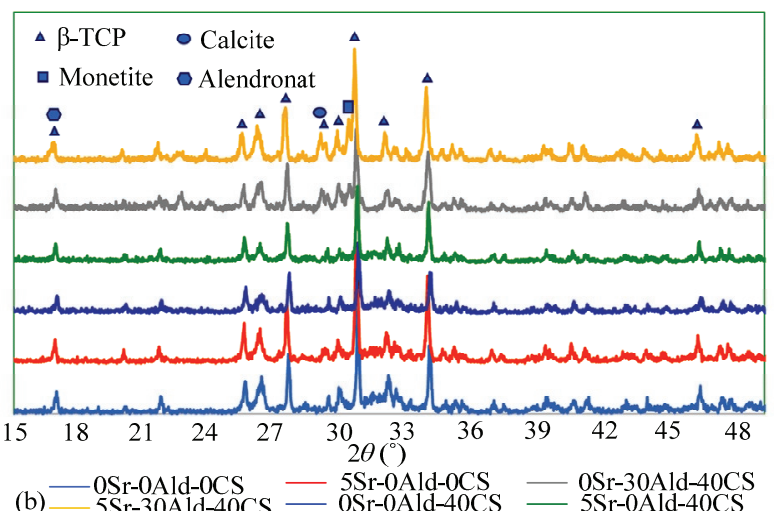

Fig. $2 X$-ray diffraction patterns of samples, (a) as-set CPCs and (b) $7 \mathrm{~d}$ soaked samples. 


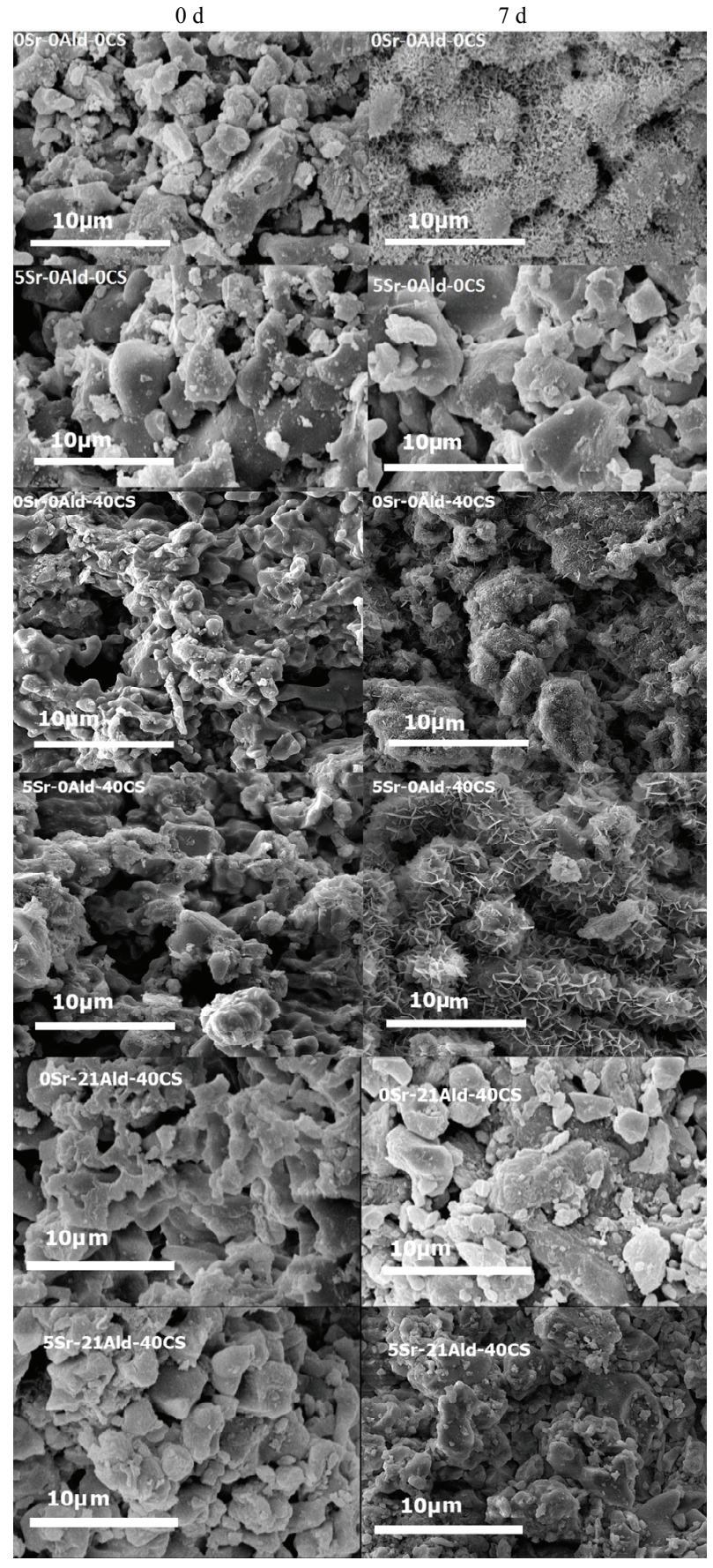

Fig. 3 SEM images of cement before and $7 \mathrm{~d}$ after immersion in Ringer's solution.

Ringer's solution was dynamically performed (Fig. 4). The results illustrated that sample dissolution was immediately started after immersion in Ringer's solution. Following the initial bursting release, ion release remained almost constant throughout the $7 \mathrm{~d}$ measurement period. Results (Fig. 4b) showed that $\mathrm{Sr}^{2+}$ ion release reached $30.53 \mathrm{mg} \cdot \mathrm{L}^{-1}$ for $5 \mathrm{Sr}-21 \mathrm{Ald}-40 \mathrm{CS}$ after $7 \mathrm{~d}$. This level is known as non-toxic and it is well within the doses believed to have positive effect on osteoblast-like cells in vitro ${ }^{[27]}$.

\subsubsection{Drug release profile and release kinetics}

Ald has no the chromophore identifiable via common spectroscopic approaches. Thus, the Ald-loaded samples were analyzed through the spectrophotometric analysis of a chromophoric complex of Ald and Fe (III) ions. The release rate of Ald from 0Sr-21Ald-40CS and 5Sr-21Ald-40CS was evaluated in the PBS by maximum adsorption of $\lambda_{\max }=236 \mathrm{~nm}$. Both samples showed a bursting release of Ald (Fig. 5). However, 5Sr-21Ald-40CS had faster release rate within the first $24 \mathrm{~h}$, in which $67.6 \% \pm 3.0 \%$ of the drug loaded was released. In addition, for both samples, the major amount of release occurred within $24 \mathrm{~h}$ and then, it slowly continued up to $168 \mathrm{~h}$. 0Sr-21Ald-40CS and 5Sr-21Ald-40CS showed nearly $70 \%$ and $79 \%$ drug release following $168 \mathrm{~h}$, respectively, and the drug release rate in 5Sr-21Ald-40CS was relatively faster than that in 0Sr-21Ald-40CS.

Table 2 lists the fit parameters of Weibull's equation and power law with the related correlation coefficients. Ald release from both CPCs conformed to Weibull's equation better than power law. For the Weibull constant $(d)$ and exponent $(n)$ in the power law, the differences in values for different samples were not statistically significant, but for $k$ and $\tau$, differences were significant.

\subsection{In vitro study}

3.2.1 RAW264.7 cell culture and seeding

Fig. 6 shows RAW264.7 cell morphology for 0Sr-0Ald-0CS, 5Sr-0Ald-0CS, 0Sr-0Ald-40CS, 5Sr-0Ald-40CS, 0Sr-21Ald-40CS, and 5Sr-21Ald-40CS after three culturing days. Spontaneous adhesion of cells was observed in all samples with extensive cellular micro-extensions. Morphologically, 0Sr-0Ald-0CS cells resembled osteoclasts. Moreover, it was observed that colloidal silica did not have any inhibitory effect during RAW 264.7 cells differentiation (0Sr-0Ald-40AC). Sr in 5Sr-0Ald-0CS and 5Sr-0Ald-40CS strongly inhibited differentiation of RAW 264.7 monocytes from 


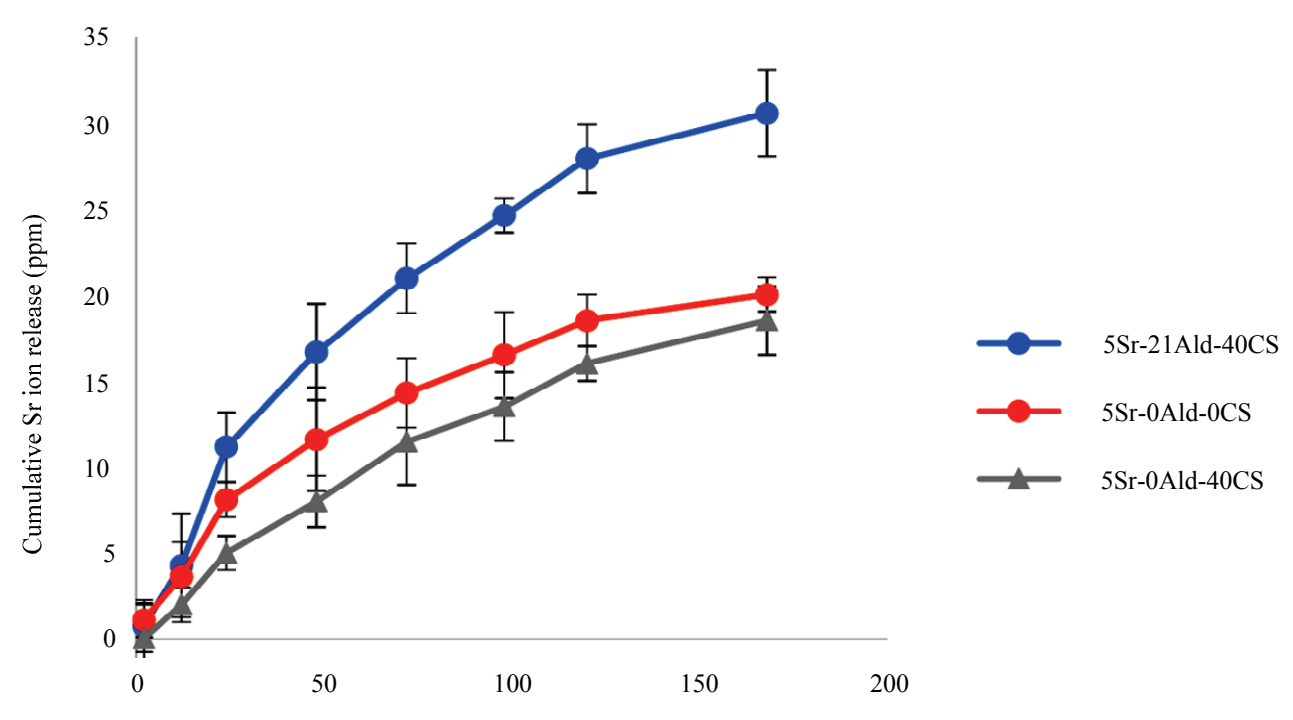

(a)

Time (h)

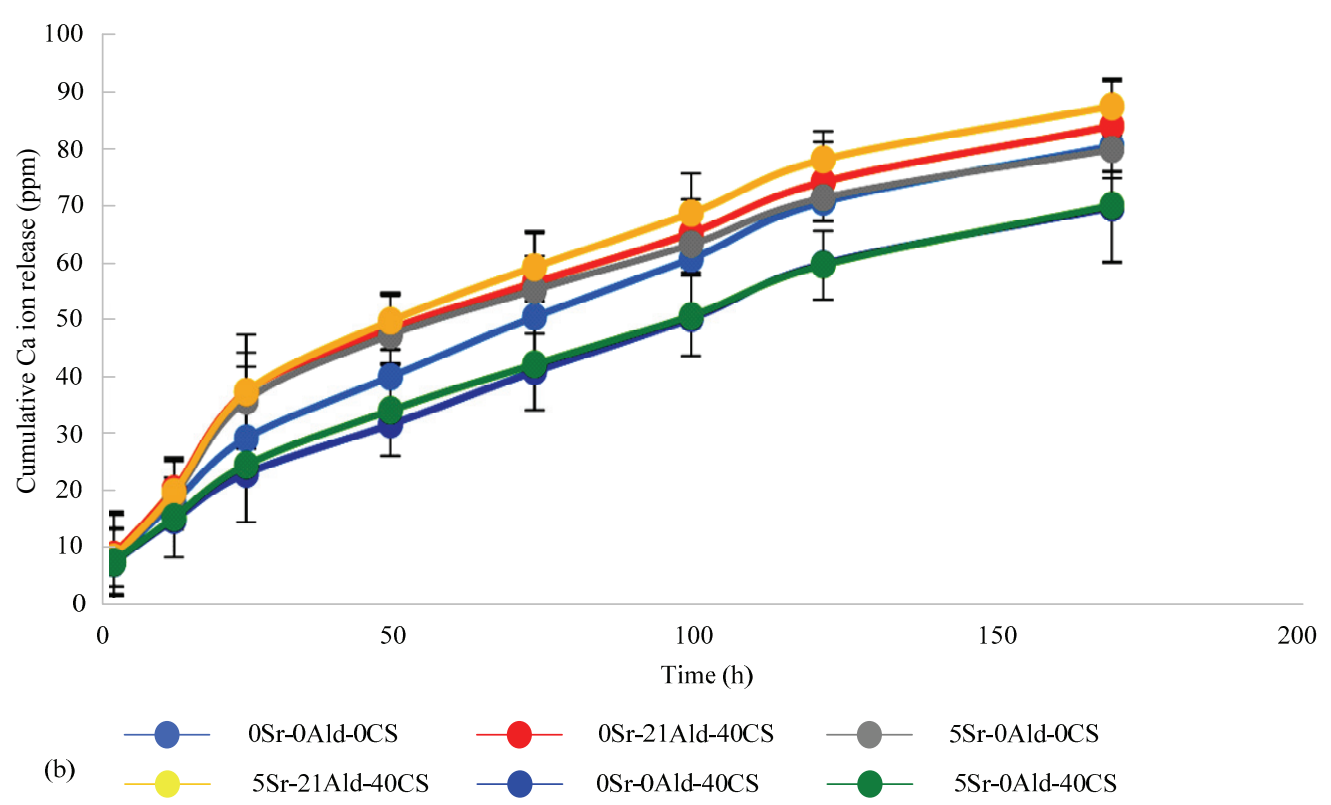

Fig. 4 Ions release in Ringer's solution during 7 d, (a) calcium release and (b) Sr release.

Table 2 Fitting parameters of Ald release from CPCs

\begin{tabular}{ccccccc}
\hline \multirow{2}{*}{ Samples } & \multicolumn{3}{c}{ Power law } & \multicolumn{3}{c}{ Weibull equation } \\
\cline { 2 - 7 } & $n$ & $k$ & $R^{2}$ & $d$ & $\tau$ & $R^{2}$ \\
\hline 0Sr-21Ald-40CS & $0.23 \pm 0.01$ & $3.39 \pm 1.52$ & 0.911 & $0.524 \pm 0.01$ & $1.30 \pm 0.24$ & 0.971 \\
5Sr-21Ald-40CS & $0.42 \pm 0.01$ & $2.17 \pm 1.82$ & 0.945 & $0.402 \pm 0.03$ & $16.90 \pm 0.51$ & 0.969 \\
\hline
\end{tabular}

osteoclasts, but in Ald loaded samples, it facilitated differentiation of osteoclast-like cells.

Besides osteoblasts, osteoclasts have a central role in remodeling the bone. In this research, RAW264.7 cells were directly seeded on the cement samples and were cultured for three days in a medium complemented with $50 \mathrm{ng} \cdot \mathrm{mL}^{-1}$ RANKL, a central growth factor in the development of osteoclast ${ }^{[28]}$. TRAP activity and cell morphology were studied to assess the effect of Ald, colloidal silica, and $\mathrm{Sr}^{2+}$ content in cements on the differentiation of RAW264.7 cells. After 3 d RAW264.7 culture, negligible TRAP activity was detected. The 


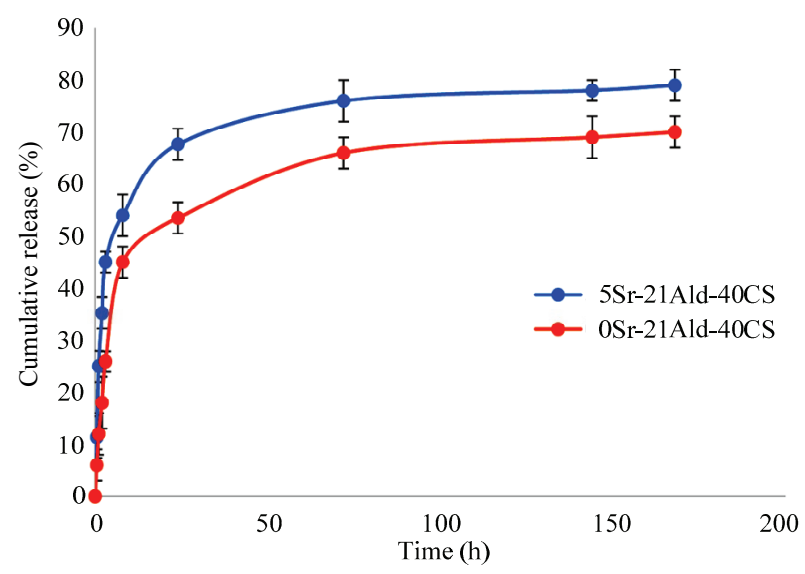

Fig. 5 Cumulative release of Ald from cement samples.

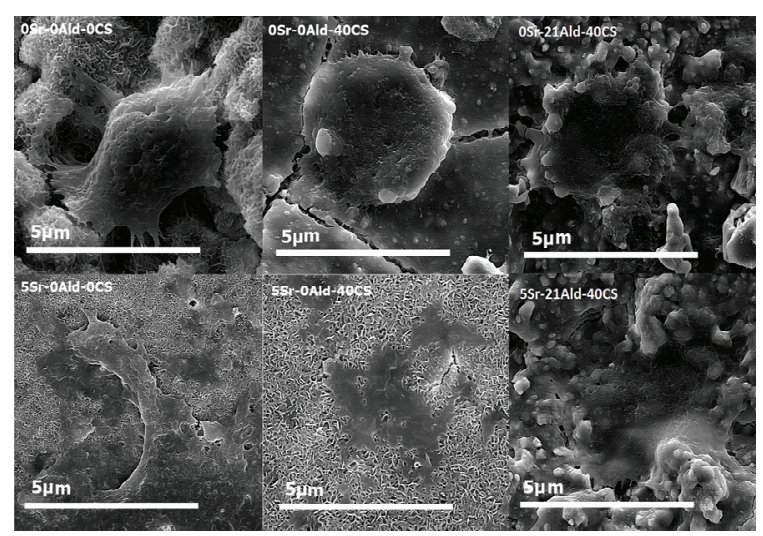

Fig. 6 RAW 264.7 cell morphology.

minimum (0.037) and maximum (0.065) values of TRAP activity were related to 5Sr-0Ald-0CS and 0Sr-0Ald-0CS, respectively (Fig. 7). However, after 5 d, the augmentation of TRAP activity was detected in all samples and TRAP synthesis by osteoclast-like cells was greatly higher in 0Sr-0Adld-0CS. Colloidal silica did not show any inhibitory effect on RAW264.7 differentiation. Interestingly, the presence of $\mathrm{Sr}^{2+}$ and Ald inhibited the differentiation of monocytes towards mature osteoclasts, but colloidal silica did not affect TRAP activity. Addition of Sr and Ald decreased the TRAP activity. Nevertheless, statistical significance was reached only for 5Sr-0Ald-0CS and 5Sr-0Ald-40CS. This result suggests that in TRAP activity the presence of $\mathrm{Sr}^{2+}$ is more effective than alendronate sodium trihydrate and colloidal silica.

\subsubsection{Osteoblast morphology}

Fig. 8 shows the morphology of $\mathrm{G}$ cells on the cement samples. G cells spread on the CPC surface. After three days, a smaller number of osteoblasts were attached to 0Sr-0Ald-0CS, although their number increased in 5Sr-0Ald-0CS. Adding colloidal silica to 5Sr-0Ald-40CS did not have any positive effect, but in 0Sr-0Ald-40CS, it increased the number of cells. Adding Ald to the samples did not influence the number of cells. Results show that adding Sr to the samples would enhance osteoblast adhesion after three days. This indicates the effective role of the doping Sr or adding Ald and colloidal silica, simultaneously, in enhancing osteoblast cell adhesion.

\subsubsection{MTT}

MTT assay was conducted to assess the cytocompatibility of the prepared cements (Fig. 9). Following the $7 \mathrm{~d}$ incubation, cell viability in all samples was reduced. However, this reduction was found negligible in all cases. Adding $5 \mathrm{wt} \% \mathrm{Sr}$ (5Sr-0Ald-0CS) increased biocompatibility of the prepared cements $(90.47 \%$ viability) in comparison to 0Sr-0Ald-0CS (79.04\%). The prepared cements had appropriate biocompatibility and were

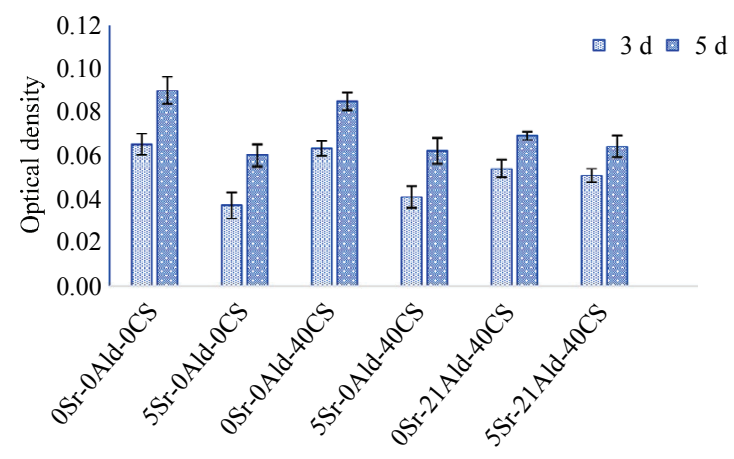

Fig. 7 TRAP activity of RAW264.7 cell.

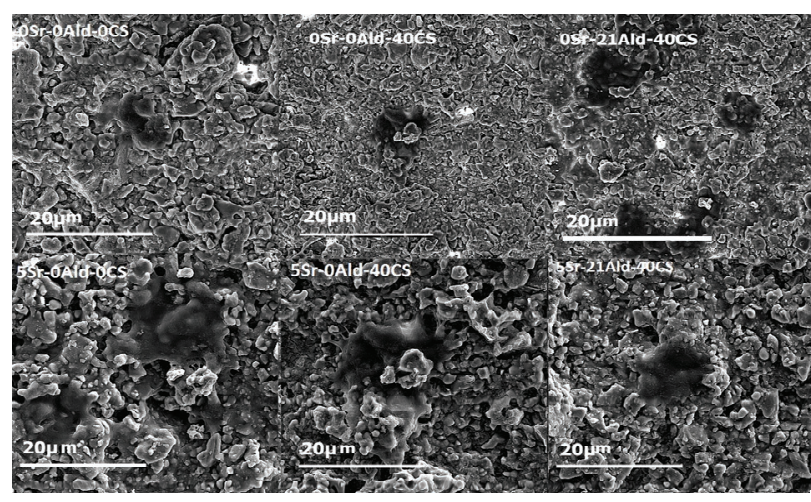

Fig. 8 Morphology of G cells. 


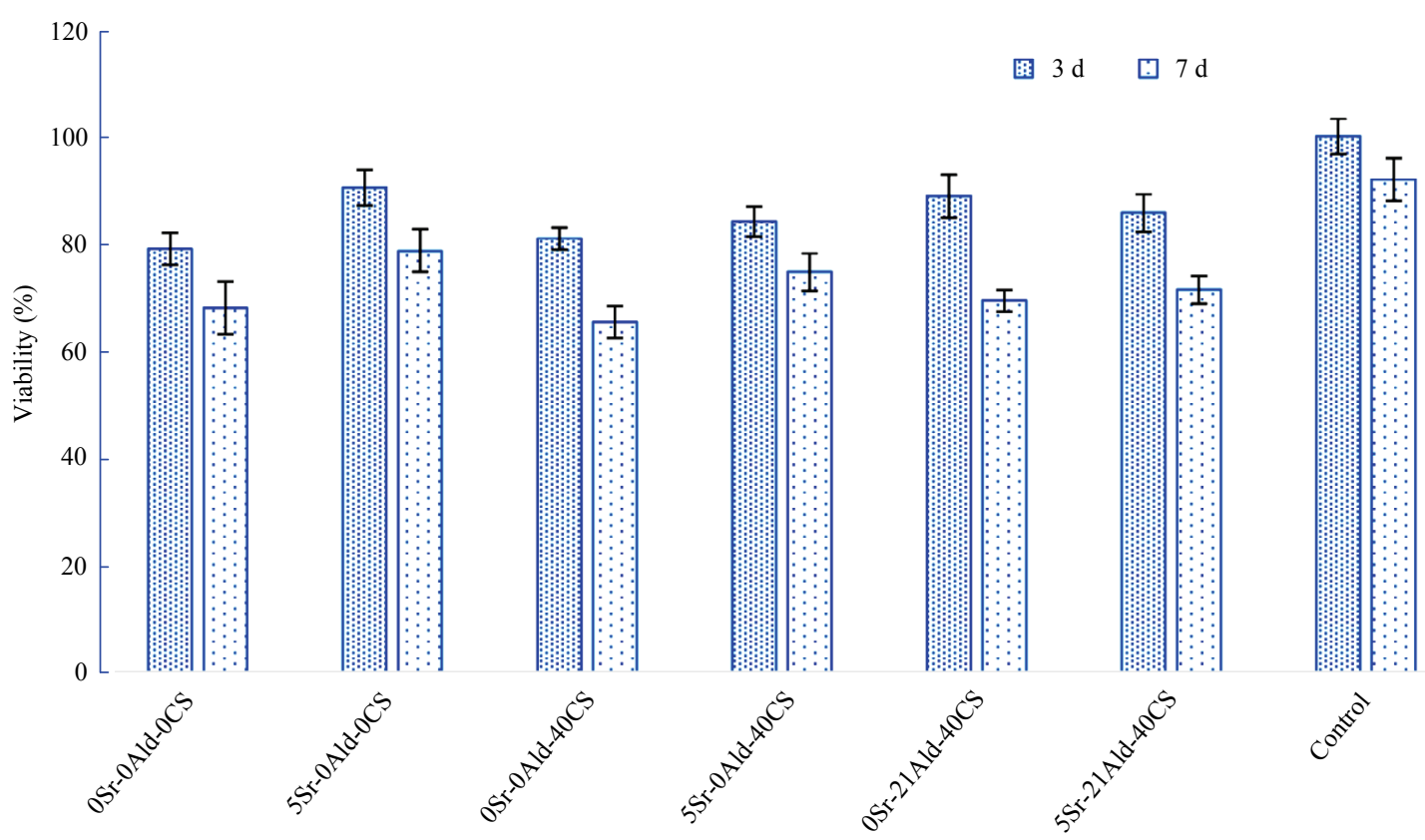

Fig. 9 MTT assay of G cells.

considered to be fit for use as bone cement. 0Sr-21Ald-40CS and 5Sr-21Ald-40CS showed 88.8\% and $85.7 \%$ viability, respectively.

Loading Ald in the cement sample in the presence of colloidal silica enhanced viability for 0Sr-21Ald-40CS (88.8) more than for 5Sr-21Ald-40CS (85.7). Colloidal silica in the cement sample with or without Sr did not have any significant impact on cement viability. MTT assay confirmed that incorporation of Ald, $\mathrm{Sr}^{2+}$, and colloidal silica in CPSC (21 mM Ald, $3 \mathrm{wt} \%$, and $40 \mathrm{v} \%$ ) had no cytotoxic effects on G cells.

\subsubsection{Alkaline phosphatase activity}

Measurement of Intracellular Alkaline Phosphatase (ALP) activity is a necessary criterion for activation and differentiation of osteoblast. ALP activity represents an early marker of osteoblast differentiation and the augmented expression of ALP corresponds to the progressive differentiation of cultured osteoblasts ${ }^{[29]}$. Fig. 10 depicts the ALP activity results of the prepared cements following $3 \mathrm{~d}$ and $7 \mathrm{~d}$ of incubation, demonstrating that adding $\mathrm{Sr}$ ions may reinforce bone cell activities. 5Sr-0Ald-0CS exhibited the highest level of alkaline phosphatase activity among all the samples. An increase in ALP activity was seen between the two time points for all samples. 0Sr-21Ald-40CS showed the highest ALP activity after 5 Sr-0Ald-0CS. This indicates that Ald and $\mathrm{Sr}$ alone in samples would enhance ALP activity. Adding colloidal silica to the cement did not change ALP activity (0Sr-0Ald-40CS).

\section{Discussion}

Local treatment of osteoporosis is a potential therapeutic method and CPCs as a carrier have been shown good in vivo biocompatibility. They can be considered as potential fillers in bone defects with the capability to be remodeled into bone ${ }^{[30-32]}$. Therefore, the present study aimed to analyze CPCs as a carrier for releasing Ald and $\mathrm{Sr}$ in the presence of colloidal silica. For evaluating properties and biocompatibility of the cement system, setting time, microstructure, drug release, and cell cytotoxicity were analyzed in vitro. Adding Sr to the cement samples increased initial and final setting times and the difference of setting times between doped and undoped cements (5Sr-0Ald-0CS and 0Sr-0Ald-0CS) was insignificant. Jayasree et al. ${ }^{[27]}$ showed that the existence of $\mathrm{Sr}^{2+}$ ion would inhibit hydrolysis of calcium phosphates and impede further HA precipitation in different CPC systems, which would result in slower setting time. This is ascribed to the minor inhibitory effect of dissolved $\mathrm{Sr}^{2+}$ on depositing rate of apatite ${ }^{[27]}$. Thus, increase in the $\mathrm{Sr}^{2+}$ concentration enhances the 


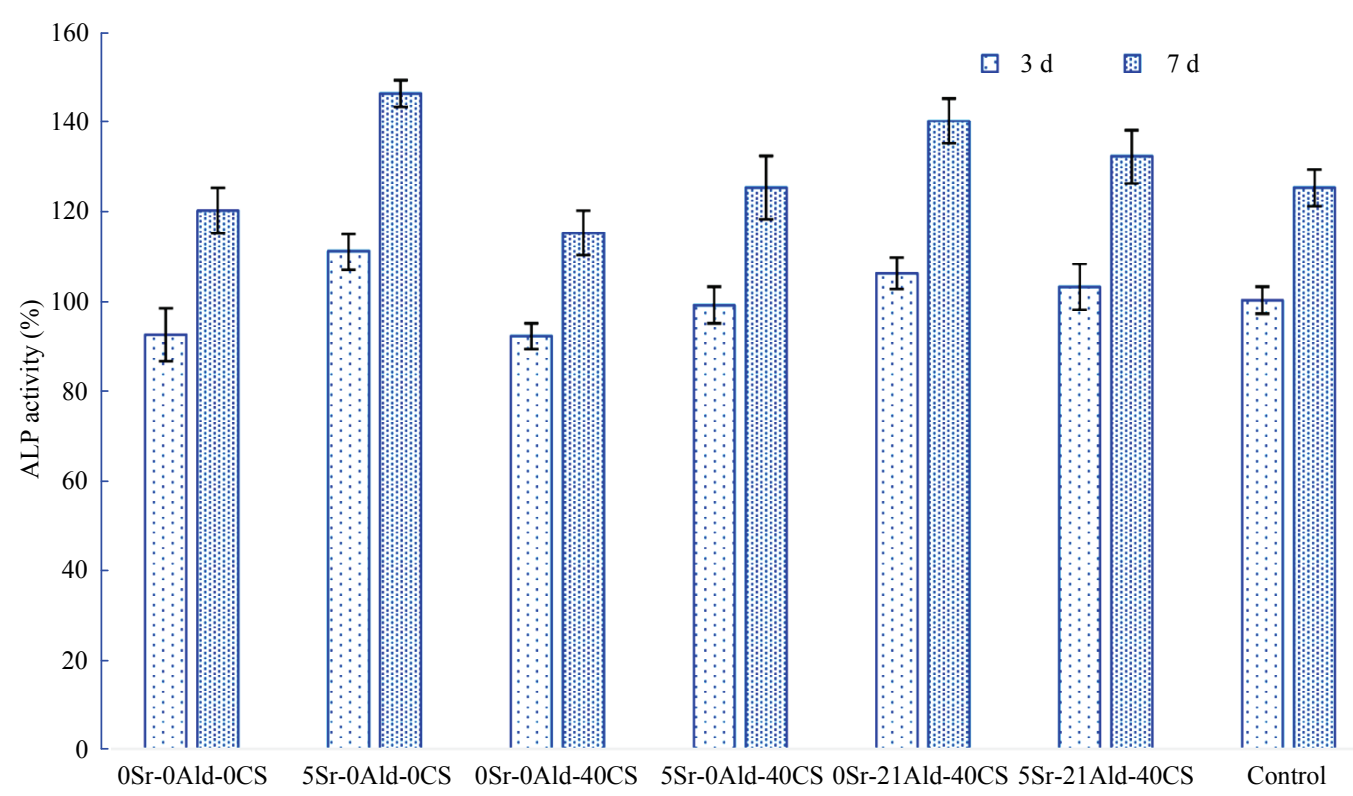

Fig. 10 ALP activity of G cells.

inhibition effect in the early hydration stages. Loading Ald greatly affected the initial and final setting times in 0Sr-21Ald-0CS and 5Sr-21Ald-0CS. Adding $21 \mathrm{mM}$ Ald to the cement formula inhibited cement setting.

Ald tends to chelate with $\mathrm{Ca}^{2+}$ ions and it affects the primary nucleation, interferes with mineral precipitation, and stops mineralization, thus putting off the setting reaction and resulting in prolonged setting times ${ }^{[30]}$. Because of their unacceptable setting times, 0Sr-21Ald-0CS and 5Sr-21Ald-0CS were omitted from the experiments. Adding colloidal silica to the liquid phase of cement shortened the setting time in all samples. The nanosilica particles made a colloidal suspension with superficial $\mathrm{OH}$ groups in cement liquid. The colloidal silica particles $(\mathrm{Si}(\mathrm{OH}))$ interacted to form a 3D-network of $\mathrm{Si}-\mathrm{O}-\mathrm{Si}$ groups ${ }^{[6,17]}$. The binding effect of the condensed particles may be the major reason for decreasing setting time of added colloidal cements. According to the diffraction patterns of the prepared samples, $\beta$-TCP, monetite, and calcite (cement ingredients) peaks were observed between $15^{\circ}<2 \theta<50^{\circ}$. As observed in Fig. 2, the substitution of calcium with $\mathrm{Sr}$ could change the crystal structure and the lowest sharp peaks were related to the Sr-doped cement. However, broadening was quite clear for all $\mathrm{Sr}$-doped samples, because of $\mathrm{Sr}^{2+}$ larger diameter in comparison to $\mathrm{Ca}^{2+}$ $\left(\mathrm{Ca}^{2+}\right.$ ionic radius $=0.100 \mathrm{~nm} ; \mathrm{Sr}^{2+}$ ionic radius $=$
$0.118 \mathrm{~nm}$ ). Adding amorphous colloidal silica, especially to $0 \mathrm{Sr}-0$ Ald-40CS and $5 \mathrm{Sr}-0 \mathrm{Ald}-40 \mathrm{CS}$, broadened the peaks also peak sharpness decrement was seen in 0Sr-21Ald-40CS and 5Sr-21Ald-40CS. Boanini et al. ${ }^{[33]}$ reported peak broadening in the presence of Ald. After the process of soaking samples in Ringer's solution for seven days, no phase transformation was observed in XRD patterns and $\beta$-TCP was the predominant phase.

The SEM micrographs of CPCs (Fig. 3) indicated that doping $\mathrm{Sr}$ in the cement sample (5Sr-0Ald-0CS) inhibited the formation of hydroxyapatite (HA) crystals in comparison with the undoped sample (0Sr-0Ald-0CS). According to Bermudez et al. ${ }^{[34]}$, this is related to the inhibitory effect of dissolved $\mathrm{Sr}$ ion on nucleation and precipitation rate of apatite. In colloidal silica-loaded sample, the structure was more compact and lower porosity was observed. Loading colloidal silica in as-set cement (0Sr-0Ald-40CS and 5Sr-0Ald-40CS) gave a more compact structure, perhaps due to the 3D-network of the $\mathrm{Si}-\mathrm{O}-\mathrm{Si}$ groups ${ }^{[6,17]}$. Moreover, after a seven-day soaking in Ringer's solution, small size of thin crystal plates of apatite was observed. It was observed that colloidal silica enhanced apatite formation. According to Fig. 3, no needle-shape microcrystals of HA were found in the as-set cement, demonstrating that HA crystals were not present prior to soaking in Ringer's solution. However, after $7 \mathrm{~d}$ with the simulated body fluid, in 
0Sr-0Ald-0CS, 0Sr-0Ald-40CS, and 5Sr-0Ald-40CS, the microstructure of the cement changed. HA micro-needle was formed in 0Sr-0Ald-0CS and 0Sr-0Ald-40CS after soaking in Ringer's solution, as depicted in Fig. 3, in a slow precipitation process, which was similar to mineralization of human bone. Loading drug in cement samples (0Sr-21Ald-40CS and 5Sr-21Ald-40CS) even in the presence of colloidal silica, inhibited apatite formation. The mechanism of inhibiting HA crystal growth is attributed to calcium complexation of Bisphosphonates (BPs). The two phosphonate groups start interacting with calcium atoms on the HA surface via bidentate chelation of deprotonated oxygen atoms. This was possible due to the $\mathrm{O}-\mathrm{O}$ distance of Ald, which was in the same range as the $\mathrm{Ca}-\mathrm{O}$ mean distances in $\mathrm{HA}^{[30]}$. A number of researchers showed that BPs would strongly interact with the cement and lengthen/inhibit setting $^{[30,35,16]}$.

As it was clear in the SEM micrograph of cements (Fig. 3), by adding colloidal silica, a compact structure was achieved. The results illustrated that the sample dissolution was immediately commenced after immersion in the Ringer's solution. The amounts of $\mathrm{Ca}^{2+}$ and $\mathrm{Sr}^{2+}$ ion release experienced an increase in the Ringer's solution in three days. Nevertheless, a slow reduction in $\mathrm{Ca}^{2+}$ and $\mathrm{Sr}^{2+}$ was seen after $7 \mathrm{~d}$ and it could be attributed to their probable role in the apatite layer formation. The results showed that highest release rates of $\mathrm{Ca}^{2+}$ belonged to 5Sr-21Ald-40CS and then, 0Sr-21Ald-40CS with $87.2 \mathrm{ppm}$ and $83.8 \mathrm{ppm}$, respectively (Fig. $4 \mathrm{a}$ ). $\mathrm{Sr}^{2+}$ release from CPC may be applicable to treating bone defects in a way that $\mathrm{Sr}^{2+}$ concentration does not exceed the toxic limit. Obtained results showed that the $\mathrm{Sr}^{2+}$ ion release reached $30.53 \mathrm{ppm}$ for $5 \mathrm{Sr}-21$ Ald-40CS after $7 \mathrm{~d}$ (Fig. 4b).

A research on human mesenchymal stem cells showed that treatment with $65 \mathrm{mg} \cdot \mathrm{L}^{-1}$ of $\mathrm{Sr}^{2+}$ (from $\mathrm{SrCO}_{3}$ ) for $12 \mathrm{~d}$ would enhance proliferation and differentiation of cells in vitro ${ }^{[36]}$. Yang et al.$^{[37]}$ reported that MC3T3-E1 cell growth was affected by the composition of $10 \%$ Sr-doped brushite coating and induced a great amount of bone formation. Canalis et al. ${ }^{[38]}$ found that the addition of $1 \mathrm{mM} \mathrm{Sr}^{2+}$ to the cell culture medium led to increased osteoblast precursor proliferation and increased expression of extracellular matrix proteins.
Calcium release seemed to be affected by loading Ald, colloidal silica, and $\mathrm{Sr}$ substitution. Ca ion release from drug loaded samples was apparently faster than that from other samples. 5Sr-0Ald-40CS and 0Sr-0Ald-40CS showed the lowest rates of $\mathrm{Ca}$ ion. It seemed that in these samples, the compact structure created by the $\mathrm{Si}-\mathrm{O}-\mathrm{Si}$ groups 3D network led to slower rate of ion release. In the end, $\mathrm{Ca}$ ion concentrations after $7 \mathrm{~d}$ were within the range of $69 \mathrm{ppm}-84 \mathrm{ppm}$.

According to Fig. 5, 5Sr-21Ald-40CS had faster Ald release than 0Sr-21Ald-40CS and Sr substitution in CPC apparently encouraged cement dissolution. Biological activity of Sr-containing cement was evidently related to its effect on crystallinity and expansion of crystal lattice because of the larger diameter of $\mathrm{Sr}$ ion than that of Ca. Table 2 reveals the fit parameters of Weibull's equation and power law with each related correlation coefficient. Ald release from both CPCs followed Weibull's equation better than power law. For the Weibull constant $(d)$ and exponent $(n)$ in the power law, the differences in values for different samples were not statistically significant, but for $k$ and $\tau$, differences were remarkable. In the power law and Weibull's equation, " $n$ " and " $d$ " represent release mechanisms; their similar values (Table 2) indicate that Ald release mechanisms are the same for all cements, but their rates of release are not the same because " $\tau$ " and " $k$ " are dependent on geometrical and physical properties of the carrier, such as porosity and specific surface area ${ }^{[39]}$. Moreover, the values of $n$ are lower than 0.5 , a diffusion-controlled mechanism is recommended for releasing Ald from CPCs.

Fig. 6 presents morphology of the cells adhering to the surface of specimens. CPCs thoroughly supported cell attachment because of their microporous structure. Cells with polygonal morphology and extended cytoplasmic membranes were detected on the surface of samples. Fig. 6 shows that osteoclast-like cells successfully differentiated on 0Sr-0Ald-0CS surface without any inhibiting effects. However, in Sr-doped samples, no osteoclast cell was observed and $\mathrm{Sr}$ was an effective inhibitor of RAW264.7 cells differentiation. Tian et al. ${ }^{[40]}$ reported the significant role of $\mathrm{Sr}$ in RAW264.7 differentiation and TRAP activity inhibition. Apparently, Ald had an inhibitory behavior in RAW264.7 cell differen- 
tiation. RAW264.7 cells were directly seeded on the cement samples (Fig. 6). They were cultured for $3 \mathrm{~d}$ in a medium to which $50 \mathrm{ng} \cdot \mathrm{mL}^{-1}$ RANKL was added. TRAP activity was analyzed to study the influence of Ald, colloidal silica, and $\mathrm{Sr}^{2+}$ in cement on the osteoclastic differentiation of RAW264.7 cells. With respect to TRAP activity, after $3 \mathrm{~d}$, the $5 \mathrm{Sr}-0 \mathrm{Ald}-0 \mathrm{CS}$ showed the lowest TRAP activity, indicating that $\mathrm{Sr}$ would inhibit RAW264.7 cells differentiation to osteoblasts. Colloidal silica did not have any significant effect on TRAP activity and Ald slightly reduced it. Cohen-Sela et al. ${ }^{[41]}$ reported that Ald-loaded PLGA nanoparticles treatment would result in considerable inhibition of macrophage-like RAW264 cells proliferation. The observed preventing effect of Ald is attributed to some complex formation enabling endocytosis in the culture medium. Besides increased TRAP activity, the multinucleated cell formation is a characteristic of the differentiation of monocytes towards mature osteoclasts ${ }^{[41]}$, which confirms the TRAP activity (Fig. 7) and the SEM micrograph (Fig. 6) given in this research. It is clear that $G$ cells were well attached to CPC. The SEM micrograph (Fig. 8) shows that the structure of cements remarkably favored the attachment and interactions of $\mathrm{G}$ cells on the surface. The interaction of $\mathrm{G}$ cells on the material was investigated by a sequence of actions, including cell adhesion, proliferation, and differentiation. Cell adhesion and spreading was a significant step as it greatly influenced the subsequent steps of cell life. Cell adhesion is significantly affected by surface chemistry and topography ${ }^{[40,41]}$. The presence of cells on the surface of 0Sr-21Ald-40CS and 5Sr-0Ald-40CS verifies the beneficial effect of $\mathrm{Sr}$ and Ald on cell adhesion. Survivability of cells resulting from their interactions with CPC was assessed through MTT assay ${ }^{[42]}$. Our cell study confirmed that $\mathrm{Sr}$ and Ald could stimulate cell attachment and proliferation. The higher numbers of cells found on 0Sr-21Ald-40CS and 5Sr-0Ald-40CS were in agreement with MTT results. After three days, 5Sr-0Ald-0CS showed significantly higher cell viability than other samples. The MTT experiments also clearly indicated that $5 \mathrm{Sr}-0 \mathrm{Ald}-0 \mathrm{CS}$ and $0 \mathrm{Sr}-21 \mathrm{Ald}-40 \mathrm{CS}$ were the most viable samples, followed by 5Sr-0Ald-40CS and 5Sr-21Ald-40CS, and 0Sr-0Ald-40CS and 0Sr-0Ald-0CS were the least viable ones. This prolifer- ative effect was mainly driven by biocompatibility. Yang et al.$^{[37]}$ reported that $\mathrm{Sr}$ existing in calcium phosphate would stimulate early differentiation of human osteoblast cells. Tadier et al.$^{[43]}$ reported that sustained release of Sr significantly enhanced cell proliferation and differentiation. Although optimum concentration of $\mathrm{Sr}$ is widely debated, Kim and Park ${ }^{[44]}$ revealed that $\mathrm{Sr}$ ions release at $103 \mathrm{ppb}-135 \mathrm{ppb}$ increased the differentiation of osteoblast. Being consistent with other studies, the obtained results of this study demonstrated that the addition of $\mathrm{Sr}$ to cement might facilitate new bone formation.

In order to appraise cell activation and differentiation, ALP activity was first assessed. ALP activity is an early marker of osteoblast differentiation and its increased expression is associated with the progressive differentiation of cultured osteoblasts ${ }^{[38,41]}$. The results indicated that ALP activity was considerably higher (Fig. 10) in 5Sr-0Ald-0CS and then, in 0Sr-21 Ald-40CS. In this regard, 5Sr-21Ald-40CS, 5Sr-0Ald-40CS, 0Sr-0Ald-40CS, and 0Sr-0Ald-0CS followed the first two, respectively, at a meaningfully lower level. Colloidal silica loading in the cements made no differences at both time points. Replacement of $\mathrm{Ca}^{2+}$ with $\mathrm{Sr}^{2+}$ in the crystal lattice increased solubility of the mineral. On the other hand, increase in the amounts of both $\mathrm{Ca}^{2+}$ and $\mathrm{Sr}^{2+}$ in the release medium had a stimulatory effect on osteoblast proliferation. Yang et al. ${ }^{[37]}$ reported that the presence of $\mathrm{Sr}^{2+}$ would lead to increase in osteogenic differentiation. Moreover, Kuang et al. ${ }^{[45]}$ proved higher ALP activity with the presence of Sr. Thormann et al. ${ }^{[46]}$ reported that the expression of ALP, indicating mineralization of bone, was higher in the $\mathrm{Sr}-\mathrm{CPC}$ group than in the CPC group. Also, Li et al. ${ }^{[47]}$ reported that BMSCs seeded on Ald-loaded scaffold showed higher ALP activity than those seeded on CPC.

\section{Conclusion}

The aim of this article was evaluating and comparing the inhibitory effect of strontium and alendronate in calcium phosphate cement. Samples was made by adding Ald and colloidal silica to the Sr-doped calcium phosphate cement and physical and biological characteristics of the CPC were assessed to find out which one had more important role in stimulation of osteogenic 
differentiation of $\mathrm{G}$ cells and inhibition of RAW264.7 cells differentiation. Results showed that the presence of $\mathrm{Sr}$ in comparison to Ald was more effective on RAW264.7 cells inhibition and G cells differentiation. It was demonstrated that $\mathrm{Sr}$ in comparison to Ald, effectively stimulated osteogenic differentiation and had great potential for bone regeneration.

\section{Acknowledgment}

The authors acknowledge the kind financial support made available by Iran National Science Foundation (INSF) for the research under Grant No. 96015802. Moreover, the collaborations of Dr. Tayebe Ramezani and Mrs. Soraya Borna Zonouzi are acknowledged.

Open Access This article is licensed under a Creative Commons Attribution 4.0 International License, which permits use, sharing, adaptation, distribution and reproduction in any medium or format, as long as you give appropriate credit to the original author(s) and the source, provide a link to the Creative Commons licence, and indicate if changes were made.

The images or other third party material in this article are included in the article's Creative Commons licence, unless indicated otherwise in a credit line to the material. If material is not included in the article's Creative Commons licence and your intended use is not permitted by statutory regulation or exceeds the permitted use, you will need to obtain permission directly from the copyright holder.

To view a copy of this licence, visit http://creativecommons.org/licenses/by/4.0/.

\section{References}

[1] Hegde V, Jo J E, Andreopoulou P, Lane J M. Effect of osteoporosis medications on fracture healing. Osteoporos Interational, 2016, 27, 861-871.

[2] Binkley N, Blank R D, Leslie W D, Lewiecki E M, Eisman J A, Bilezikian J P. Osteoporosis in crisis: It's time to focus on fracture. Journal of Bone Mineral Research, 2017, 32, 1391-1394.

[3] Josse S, Faucheux C, Soueidan A, Grimandi G, Massiot D, Alonso B, Janvier P, Laïb S, Pilet P, Gauthier O, Daculsi G, Guicheux J J, Bujoli B, Bouler J M. Novel biomaterials for bisphosphonate delivery. Biomaterials, 2005, 26, 2073-2080.
[4] McLeod K, Anderson G I, Dutta N K, Smart R S C, Voelcker N H, Sekel R, Kumar S. Adsorption of bisphosphonate onto hydroxyapatite using a novel co-precipitation technique for bone growth enhancement. Journal of Biomedical Research Part A, 2006, 79A, 271-281.

[5] Kim S J, Park H S, Lee D W, Lee J W. Is calcium phosphate augmentation a viable option for osteoporotic hip fractures? Osteoporos International, 2018, 29, 2021-2028.

[6] Mohammadi M, Hesaraki S, Hafezi-ardakani M. Investigation of biocompatible nanosized materials for development of strong calcium phosphate bone cement: Comparison of nano-titania, nano-silicon carbide and amorphous nano-silica. Ceramic International, 2014, 40, 8377-8387.

[7] Hemmati K, Hesaraki S, Nemati A. Evaluation of ascorbic acid-loaded calcium phosphate bone cements: Physical properties and in vitro release behavior. Ceramic International, 2014, 40, 3961-3968.

[8] Rabiee S M, Moztarzadeh F, Solati-Hashjin M. Synthesis and characterization of hydroxyapatite cement. Journal of Molecular Structure, 2010, 969, 172-175.

[9] Forouzandeh A, Hesaraki S, Zamanian A. The releasing behavior and in vitro osteoinductive evaluations of dexamethasone-loaded porous calcium phosphate cements. Ceramic International, 2013, 4, 1081-1091.

[10] Rabiee S M. Development of hydroxyapatite bone cement for controlled drug release via tetracycline hydrochloride. Bulletin of Materials Science, 2013, 36, 171-174.

[11] Nosoudi N, Hasanzadeh A, Holman D, Rabiee S M, Hesaraki S, Moztarzadeh F, Gelinsky M. Calcium phosphate/etidronate disodium biocement: Etidronate, retarder or accelerator. Nano Biomedical Engineering, 2014, 6, 40-45.

[12] Otsuka M, Matsuda Y, Suwa Y, Fox J L, Higuchi W I. A novel skeletal drug delivery system using a self - setting calcium phosphate cement. 5. Drug release behavior from a heterogeneous drug - loaded cement containing an anticancer drug. Journal of Pharmaceutical Sciences, 1994 , 83, 1565-1568.

[13] Alghamdi $\mathrm{H} \mathrm{S}$, Bosco $\mathrm{R}$, Both $\mathrm{S} \mathrm{K}$, Iafisco $\mathrm{M}$, Leeuwenburgh S C G, Jansen J A, van den Beucken J J J P. Synergistic effects of bisphosphonate and calcium phosphate nanoparticles on peri-implant bone responses in osteoporotic rats. Biomaterials, 2014, 35, 5482-5490.

[14] Schlickewei C W, Laaff G, Andresen A, Klatte T O, Rüger J M, Ruesing J, Epple M, Lehmann W. Bone augmentation using a new injectable bone graft substitute by combining 
calcium phosphate and bisphosphonate as composite an animal model. Journal of Orthopedic Surgery and Research, 2015, 10, 116.

[15] C I A van Houdt, P R Gabbai-Armelin, P M Lopez-Perez, D J O Ulrich, J A Jansen, A C M Renno, J J J P van den Beucken. Alendronate release from calcium phosphate cement for bone regeneration in osteoporotic conditions. Scientific Report, 2018, 8, 15398.

[16] Shen Z H, Yu T, Ye J D. Microstructure and properties of alendronate-loaded calcium phosphate cement. Material Science Engineering C, 2014, 42, 303-311.

[17] Rabiee S M, Nazparvar N, Azizian M, Vashaee D, Tayebi L. Effect of ion substitution on properties of bioactive glasses: A review. Ceramic International, 2015, 41, 7241-7251.

[18] Bose S, Fielding G, Tarafder S, Bandyopadhyay A. Understanding of dopant-induced osteogenesis and angiogenesis in calcium phosphate ceramics. Trends in Biotechnology, 2013, 31, 594-605.

[19] Donnell M D O, Fredholm Y, de Rouffignac A, Hill R G. Structural analysis of a series of strontium-substituted apatites. Acta Biomaterialia, 2008, 4, 1455-1464.

[20] Nour S, Baheiraei N, Imani R, Rabiee N, Khodaei M, Alizadeh A, Moazzeni S M. Bioactive materials: A comprehensive review on interactions with biological microenvironment based on the immune response. Journal of Bionic Engineering, 2019, 16, 563-581.

[21] Schumacher M, Gelinsky M. Strontium modified calcium phosphate cements - Approaches towards targeted stimulation of bone turnover. Journal of Material Chemistry $B, 2015,3,4626-4640$.

[22] Schumacher M, Henß A, Rohnke M, Gelinsky M. A novel and easy-to-prepare strontium (II) modified calcium phosphate bone cement with enhanced mechanical properties. Acta Biomaterialia, 2013, 9, 7536-7544.

[23] Rabiee S M, Moztarzadeh F, Solati-Hashjin M, Salimi-Kenari H. Porous tricalcium phosphate as a bone substitute. American Ceramic Society Bulletin, 2008, 87, 43-45.

[24] Gouda R, Baishya H, Qing Z. Application of mathematical models in drug release kinetics of carbidopa and levodopa ER tablets. Journal of Developed Drug, 2017, 6, 1000171.

[25] Paolino D, Tudose A, Celia C, Marzio L D, Cilurzo F, Mircioiu C. Mathematical models as tools to predict the release kinetic of fluorescein from monoglyceride colloidal liquid crystals. Materials, 2019, 12, 693.

[26] Lindunger A, MacKay C A, Ek-Rylander B, Andersson G, Marks S C. Histochemistry and biochemistry of tartrate-resistant acid phosphatase (TRAP) and tartrate-resistant acid adenosine triphosphatase (TrATPase) in bone, bone marrow and spleen: Implications for osteoclast ontogeny. Bone and Mineral, 1990, 10, 109-119.

[27] Jayasree R, Kumar T S S, Perumal G, Doble M. Drug and ion releasing tetracalcium phosphate based dual action cement for regenerative treatment of infected bone defects. Ceramic International, 2018, 44, 9227-9235.

[28] Roy M, Bose S. Osteoclastogenesis and osteoclastic resorption of tricalcium phosphate: Effect of strontium and magnesium doping. Journal of Biomedical Material Research - Part A, 2012, 100, 2450-2461.

[29] Hesaraki S, Nazarian H, Alizadeh M. Multi-phase biocomposite material in-situ fabricated by using hydroxyapatite and amorphous nanosilica. International Journal of Material Research, 2011, 102, 494-503.

[30] Panzavolta S, Torricelli P, Bracci B, Fini M, Bigi A. Alendronate and pamidronate calcium phosphate bone cements: Setting properties and in vitro response of osteoblast and osteoclast cells. Journal of Inorganic Biochemistry, 2009, 103, 101-106.

[31] Zhao G, Cui R, Chen Y, Zhou S, Wang C, Hu Z, Zheng X, Li M, Qu S. 3D printing of well dispersed electrospun PLGA fiber toughened calcium phosphate scaffolds for osteoanagenesis. Journal of Bionic Engineering, 2020, 17, 652-668.

[32] Lin Y, Huang S H, Zou R, Gao X L, Ruan J P, Weir M D, Reynolds M A, Qin W, Chang X F, Fu H J, Xu H H K. Calcium phosphate cement scaffold with stem cell co-culture and prevascularization for dental and craniofacial bone tissue engineering. Dental Materials, 2019, 35, 1031-1041.

[33] Boanini E, Gazzano M, Rubini K, Bigi A. Composite nanocrystals provide new insight on alendronate interaction with hydroxyapatite structure. Advanced Material, 2007, 19, 2499-2502.

[34] Bermúdez O, Boltong M G, Driessens F C M, Planell J A. Development of an octocalcium phosphate cement. Journal of Materials Science: Materials in Medicine, 1994, 5, 144-146.

[35] Bigi A, Boanini E. Calcium phosphates as delivery systems for bisphosphonates. Journal of Functional Biomaterial, 2018, 9, 6 .

[36] Schumacher M, Lode A, Helth A, Gelinsky M. A novel strontium(II)-modified calcium phosphate bone cement stimulates human-bone-marrow-derived mesenchymal stem cell proliferation and osteogenic differentiation in vitro. Acta 
Biomaterialia, 2013, 9, 9547-9557.

[37] Yang L, Perez-amodio S, Barrere-de Groot F Y F, van Blitterswijk C A, Habibovic P. The effects of inorganic additives to calcium phosphate on in vitro behavior of osteoblasts and osteoclasts. Biomaterials, 2010, 31, 2976-2989.

[38] Canalis E, Hott M, Deloffre P, Tsouderos Y, Marie P J. The divalent strontium salt S12911 enhances bone cell replication and bone formation in vitro. Bone, 1996, 18, 517-523.

[39] Papadopoulou V, Kosmidis K, Vlachou M, Macheras P. On the use of the Weibull function for the discernment of drug release mechanisms. International Journal of Pharmaceutics, 2006, 309, 44-50.

[40] Tian M, Chen F, Song W, Song Y C, Chen Y W, Wan C X, Yu $\mathrm{X} \mathrm{X}$, Zhang X H. In vivo study of porous strontium-doped calcium polyphosphate scaffolds for bone substitute applications. Journal of Material Science: Material Medicin, 2009, 20, 1505-1512.

[41] Cohen-Sela E, Rosenzweig O, Gao J C, Epstein H, Gati I, Reich R, Danenberg H D, Golomb G. Alendronate-loaded nanoparticles deplete monocytes and attenuate restenosis. Journal of Control Release, 2006, 113, 23-30.

[42] Banerjee S S, Tarafder S, Davies N M, Bandyopadhyay A, Bose $\mathrm{S}$. Understanding the influence of $\mathrm{MgO}$ and $\mathrm{SrO}$ binary doping on the mechanical and biological properties of $\beta$-TCP ceramics. Acta Biomaterialia, 2010, 6, 4167-4174.
[43] Tadier S, Bareille R, Siadous R, Marsan O, Charvillat C, Cazalbou S, Amédée J, Rey C, Combes C. Strontium-loaded mineral bone cements as sustained release systems: Compositions, release properties, and effects on human osteoprogenitor cells. Journal of Biomedical Material Research, 2012, 100, 378-390.

[44] Kim T G, Park B. Synthesis and growth mechanisms of one-dimensional strontium hydroxyapatite nanostructures. Inorganic Chemistry, 2005, 44, 9895-9901.

[45] Kuang G M, Yau W P, Wu J, Yeung K W K, Pan H, Lam W M, Lu W W, Chiu K Y. Strontium exerts dual effects on calcium phosphate cement: Accelerating the degradation and enhancing the osteoconductivity both in vitro and in vivo. Journal of Biomedical Research Part A, 2014, 103, 1613-1621.

[46] Thormann U, Ray S, Sommer U, Elkhassawna T, Rehling T, Hundgeburth M, Henß A, Rohnke M, Janek J, Lips K, Heiss C, Schlewitz G, Szalay G, Schumacher M, Gelinsky M, Schnettler R, Alt V. Bone formation induced by strontium modified calcium phosphate cement in critical-size metaphyseal fracture defects in ovariectomized rats. Biomaterials, 2013, 34, 8589-8598.

[47] Li M, Mondrinos M J, Chen X S, Gandhi M R, Ko F K, Lelkes P I. Elastin blends for tissue engineering scaffolds. Journal of Biomedical Material Research Part A, 2006, 79, 963-973. 